\title{
Egyptian Irrigation
}

\section{Author(s): Colin C. Scott Moncrieff}

Source: The Geographical Journal, Vol. 35, No. 4 (Apr., 1910), pp. 425-428

Published by: geographicalj

Stable URL: http://www.jstor.org/stable/1777022

Accessed: 26-06-2016 20:06 UTC

Your use of the JSTOR archive indicates your acceptance of the Terms \& Conditions of Use, available at

http://about.jstor.org/terms

JSTOR is a not-for-profit service that helps scholars, researchers, and students discover, use, and build upon a wide range of content in a trusted digital archive. We use information technology and tools to increase productivity and facilitate new forms of scholarship. For more information about JSTOR, please contact support@jstor.org.

The Royal Geographical Society (with the Institute of British Geographers), Wiley are collaborating with JSTOR to digitize, preserve and extend access to The Geographical Journal 
(1) In a tendency to ascribe to geographical influences many results which have arisen from not only geographical influences, but from historical, racial, or even accidental influences. Already it is noticeable among writers who are enthusiastic over geographical influences, that there is a tendency to give undue weight to them.

(2) There is danger of too hasty generalizations, without enough specific examples to warrant the generalization.

(3) There is danger of a vagueness and indefiniteness in the treatment of geographical influences in human affairs because of the very largeness of the subject. When an author of a high school text-book attempts to treat these influences in the limited space at his disposal, vagueness is almost unavoidable. If the new type of geography shall come to be taught in the schools, there will be need of taking up only a limited number of geographical influences, and of working these out in detail, rather than taking up a large number of influences which necessarily can receive scarcely more than mention.

(4) The teachers who will be called upon to teach this new type of geography will, for the most part, be themselves inexperienced and unprepared. They will not have had similar courses in normal schools or colleges. This must be borne in mind in our consideration of whether or not the present trend is likely to lead to better results.

Unmistakably the trend is in the direction which has been pointed out. Undoubtedly new text-books constructed along these lines will be forthcoming. It will be unfortunate if, in our zeal for humanized geography, we should advance too rapidly, and thus, perhaps, bring into disrepute the very movement which we believe ought to result in a distinct educational gain.

Personally, I am strongly favourable to the humanizing of high school geography. I hope to see the movement gain headway as fast as it reasonably can. But I do not anticipate that the movement will go forward without mistakes and without set-backs. But, to me, the humanized course is so much richer in content, so much more valuable in giving culture, and so much more liberalizing in its influence, that I cannot resist the conviction that we shall be educationally benefited by such a course in the high schools if it can be judiciously handled.

\section{EGYPTIAN IRRIGATION.*}

\section{By Colonel Sir COLIN C. SCOTT MONCRIFFF, K.C.M.G., K.C.S.I.}

IT is generally admitted that when the English occupation of Egypt commenced in 1883 , there was no branch of the administration in a more corrupt and inefficient condition than that on which the very life of the country depended, the irrigation. In no department has there been a greater improvement. Money has been no doubt lavisbly spent, but it has been spent with judgment and ability, and it yields a magnificent revenue. When one sees the great monuments of Egyptian skill in classical times, it seems strange that a nation capable of designing and erecting such buildings apparently never thought of controlling the river on which they depended. Nor was it until early in the last century that, acting on the advice of competent French engineers, a serious effort was made to throw a dam across the two branches of the river at the apex of the delta. It was boldly designed, and in some respects well executed, but M. Mougel, its engineer, received little support or encouragement. A bad fracture took place in 1867, and it was not until the arrival of the English

* Report on the Irrigation Departments of Egypt and the Sudan for the year 1908 
engineers seventeen years after that any effort was made to repair the fracture or complete the work. The finances of Egypt were then in a deplorable state, and the country owes it to Lord Cromer's force of character and just appreciation of its wants, that he insisted on a million sterling being laid aside for the improvements of the irrigation works. With this sum at their disposal the course was clear for the English engineers, and the first work to be taken in hand was the completion and strengthening of Mougel's barrage. Until this was accomplished there was nothing to prevent about 70 per cent. of the volume of the Nile flowing out to the sea, just at the time it was most in demand for the summer irrigation of the cotton crop. Once it was completed, and the water was held up 12 feet above the barrage, the supply of the river was so effectively diverted into the canals and thence on to the fields, that one might often see children and donkeys fording the river down-stream of the barrage instead of paying a halfpenny toll for crossing the bridge.

But this was not enough. Mougel's barrage raised and diverted the river during low Nile, but did nothing to store the great volume that rolled out to the sea during Nile flood, a volume more than thirty times as great as the discharge of the low Nile. It was not till some twelve years after the British occupation that the finances of Egypt allowed this great subject to be tackled, and the Aswan dam was constructed, ponding up the river 75 feet, and creating a lake in Nubia nearly 200 miles long. Mougel's barrage only served the purposes of the Delta. South of Cairo the only irrigation effected was by means of the flood waters. With exception of one important canal in Middle Egypt, there was no water available for the cotton and sugar-cane crop. The great dam at Aswan supplied perennial water for Middle Egypt, and to divert it from the river on to the fields a dam was constructed at Assiut, similar to Mougel's barrage.

But the thirst of the land exceeded even this great water-supply. South of Assiut there was still only flood irrigation, and there was no water available to do more. It was resolved, therefore, to raise the Aswan dam 23 feet, thereby increasing by two and a quarter times the volume stored. This great work should be finished in 1912, and will supply perennial water for all the Nile valley north of Aswan.

In order to control the discharge south of Assiut, another dam has just been completed at Isna, 98 miles north of Aswan. The construction of this dam reflects the greatest credit on the engineers and contractors who carried it out. It consists of 120 openings, each 5 metres wide. The width of flooring (that is, the width of the river) is 2820 feet. The work was completed in less than three years, at a cost of about a million sterling. It will supply perennial irrigation to about 100,000 acres on the west bank, and 80,000 acres on the east bank, of the Nile.

But the outlay on the conversion of flood to perennial irrigation is far from being finished with the completion of the Assiut and Isna dams. It has been necessary to construct a costly network of new canals to carry the water to every part of the Nile valley. The new main canal on the west bank from the Isna dam will be 56 miles long, and on the eastern bank 45 miles. Including bridges, sluices, and other masonry works, there will be an outlay of about $£ 500,000$.

In Middle Egypt, the irrigation of which depends on the Assiut dam, the process of converting flood into perennial irrigation has been going on for some time. Up to the end of 1908, an area of 370,000 acres had been converted at a cost of $£ 3,800,000$. The increased rental value of the land is about $£ 5$ per acre, and the sale value about $£ 50$ per acre. To complete the conversion works in the Giseh province will require an outlay of about $£ 668,000$, and the value of the land will be enhanced in about the same proportion as the above.

In 1883 there were no roads in Egypt outside of the towns, and it was impossible 
to drive a cart from Alexandria to Cairo. Camel carriage is always difficult in moist irrigated land. Navigation on the numerous canals was generally obstructed in order to increase the revenue of the State railway, which was hypothecated to the national debt, and there were heavy tolls impised on the boat traffic on the river. Now the Nile is free of tolls. There is an excellent system of agricultural roads throughout the country, and more than 100 miles were added to it this last year. On some of these roads light railways are now being constructed.

When irrigation in Egypt fell into English hands, the engineers soon recognized that the task of carrying surplus water off the land would be as difficult as that of carrying it on to the land, and the more the irrigation increased the more was the need for drainage. This was largely due to the very faulty alignment of the old canals, which repeatedly crossed the drainage outfalls, and in the delta to the extreme flatness of the country and the difficulty of obtaining a satisfactory outfall into the tideless Mediterranean. Much of the province of Behera is below the sealevel, and everywhere along the sea-face there were extensive swamps. Inland, also, there were large areas of sodden and water-logged country which once had been fertile.

Early measures were taken to remedy this evil, but unfortunately the million loan was ear-marked for irrigation and not for drainage works, and it was not easy to find money for thése last. The subject, however, was not neglected, and many hundreds of miles of drainage channels, some with beds of not less than 60 feet wide, have been constructed. In the year 1908 there was an outlay of about $£ 115,000$ on excavating new drains and in maintaining and clearing existing ones. But more is necessary. It is said in this report, "Notwithstanding the increased expenditure, it cannot be said that the drainage is satisfactory, although improvement has certainly been made in recent years. Complaints are frequently made that the drains are full of water, and not working properly." The beds become choked with weeds, and the slope of the channels is insufficient. The only remedy for this must be the erection of powerful steam-pumps along the seaboard. There are some already, but more are required. Artificial drainage by means of pumps is a very costly process, as they know well in Holland. But the readers of this report must see that Egypt, small country as it is, does not shrink from freely spending money when it is certain of a golden harvest.

Irrigation in the Sudan.-The poverty, the scanty population, and the lack of water in the Sudan form a striking contrast to the dense population and the wealth of Egypt. At present it is little better than a derelict estate commanding no value in the market. Much money has been already spent on it (including the railway to the Red sea), and much more must be spent, but population cannot be created in a hurry. Money can only be procured in exchange for abundant harvests. Harvest can only be produced by irrigation, and at present for many months in the year there is no, water wherewith to irrigate. Egypt paid for the great Aswan dam, and naturally lays claim to the water it stores. But with the dam raised 23 feet, there ought to be water enough to irrigate a large area in the Sudan.

An irrigation scheme on a great scale is not a thing to be hurried. It is first necessary to make a very careful survey of the tract to be watered. Lines of levels require to be fixed with the greatest accuracy -an error of 6 inches in a couple of miles being inadmissible. At the same time the sources of water-supply throughout the whole year must be studied, the rainfall as well as the supply from rivers. A study at the same time is necessary of the soil proposed to be watered. A scheme of drainage must be worked out. The advantages and disadvantages of combining navigation with irrigation must be weighed. The resources of the country-its timbers, its stone, its climate. Information on all these points must be obtained 
before a spade is put in the ground, and there must be considered whether there is population sufficient to enable the work to be done by manual labour, or whether mechanical power must be used.

This preliminary study is still far from complete, but enough is known to decide that it would be feasible to make a great canal taking out of the left bank of the Blue Nile near Sennar, and flowing in a north-westerly direction generally parallel to that river. After flowing about 30 miles the canal would have command of the country near Wad Medani, and from there onwards for about 50 miles it would flow through rich black soil. So far as the levels of the country are concerned, and given a sufficient water-supply, such a canal as this might irrigate three millions of acres. But considering the sparseness of population and their total ignorance of irrigation, the chief engineer reports that "for purposes of discussion and estimates of possible cost, half a million feddans would seem to be indicated as a probably suitable area to be worked up to in the course of the next fifteen or twenty years." He thinks that this canal might perhaps be made for $£ 3,000,000$, or $£ 6$ per feddan benefited. So far as our knowledge of the Sudan goes, this Gezira canal is its most promising irrigation scheme.

From the foothills of Abyssinia there comes a torrent known as the Gash, which flows in a north-westerly direction past the town of Kassala, and loses itself in the desert. In the Gash valley the rains begin about the middle of June, reach Kassala early in July, and by the end of September the Gash has ceased to flow till the following June. While the rains last the Gash is a formidable river, but it is most uncertain in its flow. Irrigable land of first-class quality is commanded by the Gash, but the water-supply must be very limited unless it admits of storage, which is not probable, and the chief engineer considers 300,000 acres as the limit of irrigation possible. It is clear that irrigation from the river Gash is a problem beset with difficulties. A weir with a crest of 100 metres was built across the river, and was carried away in 1906. Again it was rebuilt in 1907, and is standing now. A small canal is drawn from the river above this weir, and some cotton and millet cultivation is practised near Kassala, but it is too soon to forecast any satisfactory irrigation from the Gash.

The whole of this irrigation report for 1908 is full of valuable information, and proves how ably the department is being administered.

\section{NEW LIGHT ON VERRAZZANO'S VOYAGE OF 1524.}

The name of the Florentine navigator, Giovanni da Verrazzano, has lately been brought before the public in connection with the Hudson celebration at New York (Journal, vol. 32, p. 575), from the fact (for such it has generally been conceded to be, in spite of attempts to discredit Verrazzano's narrative) that Hudson had been forestalled in his discovery of the Budson river by the earlier voyager, who sailed in 1524 in the service of the King of France. At the time of the celebration the Florentine was duly honoured by the Italian colony in New York by the inauguration of a monument in that city, while simultaneously, in Rome, a discovery of much importance for the knowledge of his voyage was made in the bringing to light of a previously unknown version of the explorer's report, which, besides confirming in a most satisfactory way the authenticity of the voyage, adds some valuable details to the accounts previously available. A full discussion of this interesting find, with a verbal reprint of the document and facsimiles of portions of it, was contributed by Signor A. Bacchiani to the Bollettino of the Italian Geographical Society for November last. 